\title{
THE TOPICAL ASPECTS OF FOREIGN STUDENT SOCIOCULTURAL ADAPTION IN UKRAINIAN HIGHER EDUCATION INSTITUTIONS
}

\author{
Maria Andriushchenko ${ }^{1}$, Mariana Shkolyar ${ }^{2}$ \\ Lviv Polytechnic National University, Lviv, Ukraine \\ ${ }^{1}$ Student, Department of Sociology and Social Work \\ ${ }^{2}$ Candidate of Political Science, Associate Professor, Department of Sociology and Social Work
}

Background: In the context of globalization and integration, the intensity of communication between representatives of different ethnic cultures increases. This process provokes both positive and negative consequences. This is especially important to study for the international students, as it is group most numerous in the territory of Ukraine.

Purpose: outline topical aspects of sociocultural adaptation of foreign students in Ukrainian higher education institutions.

Methods: The theoretical method of research was to analyze the documents used to study the works of scientistics who researched socio-cultural adaptation of foreign students. The method of document analysis was also used: statistical reports of the Kiev International Institute of Sociology and the Ukrainian State Center for International Education were analyzed.

Results: Study shows that creating a favorable socio-cultural atmosphere is important for foreign students at universities in Ukraine. The adaptation is an important period in the life of a foreign student, because it is conditioned by a new sociocultural environment. Sociologists analyze the sociocultural adaptation of foreign students in the communication process. Since, in the process of intercultural communication between representatives of different ethnic communities, experience, knowledge about culture, language, etc. are exchanged, new personal values are formed.

Conclusion: Adaptation of foreigners in the educational, cultural and professional sphere will strengthen Ukraine's role in the European space and create a positive image as a multicultural and tolerant country. Successful adaptation of migrants requires the following conditions: communication with a new environment, knowledge of a foreign language, positive motivation, participation in local events related to the host culture, and access to mass media.

Keywords: socio-cultural adaptation, integration, "cultural shock", intercultural dialogue, migrants, foreign students, ethnic discrimination, tolerance.

Інтерес до дослідження адаптації іноземців в державах-реципієнтах зумовлений тим, що сучасне суспільство характеризується значними міграційними процесами, глобалізацією, високим ступенем культурної різнорідності. В умовах глобалізації та інтеграції зростає інтенсивність комунікації між представниками різних етнічних культур. Такий процес провокує як позитивні наслідки, так і негативні. Серед позитивних можемо виділити: збагачення соціуму культурним різномаїттям, обмін знаннями та традиціями, виховання толерантності в умовах міжетнічного діалогу, поштовх для державної влади, заохочувати та регулювати міжетнічні та міжрасові відносини. Проте, маємо і негативні наслідки, такі як: загроза міжнаціональній єдності, що може спровокувати міжрасову та міжетнічну недовіру, ускладнення процесу асиміляції та інтеграції іноземців, посилення агресії та насильства між представниками різних етнічних груп.

Оскільки, за останніми даними Українського державного центру міжнародної освіти, в українських 3ВО навчається 75605 іноземців, проблема соціокультурної адаптації іноземців залишається актуальною (Український державний центр міжнародної освіти, 2019). Основними причинами, що спонукають іноземних студентів здобувати освіту в Україні, є: легкість вступу до ЗВО, низька плата за навчання, розташування країни, тощо. Проте, чи зможе така тенденція зберегтися і надалі, залежить і від соціокультурних умов, зокрема, таких як: рівень толерантності до іноземців, безпека проживання, можливість професійного розвитку та самореалізації, тощо. Теоретична та практична актуальність зазначеної проблеми зумовлює необхідність наукового аналізу специфіки навчання іноземних студентів в 
українських 3ВО, зокрема, - особливостей їх соціокультурної адаптації, міжкультурних відносин, рівня толерантності сучасного українського суспільства до зовнішніх мігрантів.

У своєму дослідженні ми зверталися, перш за все, до робіт соціологічного, психологічного, культурологічного та антропологічного напрямків. Вагомими $є$ дослідження проблем соціокультурної адаптації мігрантів таких закордонних вчених, як Дж. Беррі, Д. Катц, Т. Адорно, Е. Богардус, Г. Зіммель, Т. Лукман, Ж. Піаже, Г. О. Балл, Е. Еріксон, а також вітчизняних науковців, зокрема, В. Котигоренка, М. Панчук, В. Свтуха, В. Войналовича, В. Арбєніної, В. Паніотто, В. Трощинського тощо.

У соціальній психології соціальну адаптацію розглядають як “закономірності спільної діяльності, що обумовлюються загальною метою і ціннісними орієнтаціями соціальних груп” (Добротвор, Щербина, 2017). Т. Г. Стефаненко розглядає процес соціокультурної адаптації 3 позиції етнопсихології. Нею були виділені кілька факторів, які впливають на сприятливість взаємодій представників різних етносів, серед яких: тривалість взаємодії (постійна, тривала, короткочасна), територія, на якій спілкуються індивіди, мета спілкування (сумісна діяльність, навчання, проживання тощо), частота i глибина контактів, кількісне співвідношення (більшість-меншість), явні розпізнавальні ознаки (мова, раса тощо) (Беспалова, Самойленко, 2015). В культурології соціокультурну адаптацію визначають як пристосування людських суспільств, соціальних груп та індивідів до природно-географічних та історичних умов, які змінюються через зміну стереотипів свідомості й поведінки, форм соціальної організації та регуляції, норм і цінностей, способу життя та життєзабезпечення (Добротвор, Щербина, 2017). Соціологи аналізують соціокультурну адаптацію іноземних студентів в процесі комунікації. Оскільки, у процесі міжкультурної комунікації між представниками різних етнічних спільнот відбувається обмін досвідом, знаннями про культуру, мову тощо, відбувається формування нових особистих цінностей. Метою досліджень міжетнічних зв'язків є створення відповідних умов для того, щоб в момент, коли іноземний студент потрапляє в нове середовище, він отримав нові знання, ознайомився 3 традиціями держави-реципієнта, розвинув комунікативні навички, а також розкрився з нового боку.

Потреба в адаптації є обов'язковою в житті іноземного студента, адже вона зумовлюється новим соціокультурним середовищем, а також відмінностями в культурі (мова, традиція, культурні цінності тощо). Незмінним явищем в процесі адаптації є «культурний шок». П. Адлер наголошує на тому, що феномен «культурного шоку» може мати і негативні прояви, проте його наслідком стає засвоєння нових цінностей, установок і проявів поведінки (Бардіна-Віж'є, 2019). На цьому етапі для іноземного студента важливий рівень толерантності приймаючої країни. Відсутність агресії та конфліктних ситуацій прискорять процес його адаптування до нової культури. Американська дослідниця Я.Кім в своїх працях досліджувала міжкультурну комунікацію в теорії соціальної адаптації. Згідно з концепцією дослідниці, головний елемент цього процесу $є$ переживання стресів. Це відбувається за принципом «два кроки вперед-один крок назад», що означає періодичні кризові ситуації, які заповільнюють процес адаптації. Для успішної адаптації мігрантів необхідні такі умови: спілкування з новим середовищем, знання іноземної мови, позитивна мотивація, участь в місцевих подіях, пов'язаних з культурою приймаючої сторони, і доступ до засобів масової комунікації (Корзун, 2017).

Протягом 2004-2014 років науковці Харківського національного університету імені В.Н. Каразіна 3 використанням якісних і кількісних методів отримання соціологічної інформації визначили етапи соціокультурної адаптації іноземних студентів (Бардіна-Віж’є, 2019). Перший етап характеризується ентузіазмом, захопленням, позитивними емоціями та поверхневим спілкуванням з представниками приймаючої держави. Цей етап є важливим, адже від того, які емоції отримав студент, залежить його подальше проживання в країні. На другому етапі, студенти починають ближче знайомитися 3 новою культурою, відчувають усі відмінності між традиціями їхньої країни і держави-реципієнта. Можуть відчувати на собі поділ на «чужий» та «своїх». Такі процеси можуть призвести до тривоги, внутрішньої невизначеності студента. Цей процес характеризується бажанням говорити своєю мовою, дратівливістю та відразою до нової країни, небажанням спілкуватися 3 місцевими 
громадянами. Як наслідок, пошук представників своєї культури, замикання у певних колах, які складають представники однієї етнічної групи. Третій етап включає два процеси. Перший - це бажання неодмінно поїхати додому, навіть не дочекавшись закінчення навчання. Так як, більшість студентів чують негативну відповідь від батьків, щодо повернення додому, то вони змушені пристосовуватися до нового середовища. Друга половина етапу включає - інтенсивне вивчення мови, більш близьке вивчення місцевої культури, прийняття «інакшості» як об'єктивної реальності. На четвертому етапі студенти починають відчувати оптимістичні настрої. Більша частина студентів покращують зв'язки з місцевими жителями, знаходять близьких друзів серед громадян приймаючої держави, відвідують культурні заклади, виявляють інтерес та цікавість до української культури та традицій. Заключний п'ятий етап характеризується повною адаптацією іноземця. Він готовий до самореалізації в професійній діяльності, легко йде на контакт з місцевими жителями (Бардіна-Віж'є, 2019). Успіх соціокультурної адаптації іноземців до українського середовища залежить від багатьох суб'єктивних та об'єктивних чинників. По-перше, це їхній рівень інтеріорізації нових умов та середовища; по-друге, оволодіння мовою для ведення міжкультурного діалогу; по-третє, психологічні та когнітивні характеристики індивіда; по-четверте, це вміння зберегти власну ідентичність i інтегруватися до нової культури одночасно. Зазначені характеристики впливають на кількість та якісь соціальних контактів, які іноземний студент будує з іншими, на можливість його самореалізації; вміння пристосуватися до ситуації, а також вийти з конфліктної ситуації (Ручка, Танчер, 2017).

Проте аналіз різних етапів, стратегій адаптації, не можуть повністю відобразити реальну ситуацію, з якою стикаються іноземні студенти. В Україні, зростає популярність радикально налаштованих, нетолератних, щодо так званих «інших» організацій, спостерігається упереджене ставлення до представників інших рас та національностей не лише з боку громадськості, а й представників правоохоронних органів, тощо. Приховування факту насильства породжує безкарність, що стимулює агресію в подальшому. Згідно 3 дослідженнями Київського міжнародного інституту соціології (КМІС), які проводилися в 2018 та 2019 рр. (Архів КМІС, 2018, 2019), в Україні поступово утворилися побутові форми дискримінації за етнічною ознакою пов'язані з неприйняттям іншої культури, мови або фізіологічних характеристик. Загалом В. Паніотто, згідно з проведеними дослідженнями виділив такі фактори появи упереджень та ксенофобії: освіта (чим вища освіта - тим нижчий рівень ксенофобіі), тип поселення (в селі вищий рівень ксенофобії, ніж в місті), регіон проживання, фінансовий статус (чим вищий рівень добробуту тим нижчий рівень ксенофобії) і вік (з віком рівень ксенофобії зростає). Найбільшу неприязнь українці відчувають до ромів, арабів та африканців, найнижчий рівень етнічних упереджень до росіян, білорусів (Архів КМІС, 2018, 2019).

Висновок: Отже, сприятлива адаптація іноземних мігрантів в освітній процес в українських ЗВО обумовлює їхню подальшу інтеграцію в різних сферах сучасного українського суспільства. Створення міжкультурних тренінгів, запровадження спеціальних предметів в навчальних закладах, які будуть спрямовані на вивчення культури міжетнічних та міжрасових зв'язків та діалогів, дозволить вивчати та аналізувати цю проблему з різних точок зору, а також нести інформацію для всього суспільства, не лише студентів та викладачів соціогуманітарних наук. Оскільки, у студентські роки відбувається процес самоідентифікації, набуття чи зміна соціального статусу, отримання нових навичок та установок, тому для іноземного студента надзвичайно важливо опинитися в таких умовах, які будуть сприяти позитивній адаптації, а також соціалізації в новому середовищі. Адаптація іноземців в освітній, культурній, професійній сфері дозволить зміцнити роль України в європейському просторі та створить позитивний імідж як полікультурної та толерантної країни.

\section{Список використаних джерел}

Архів КМІС, (2018, 2019). Міжетнічні упередження в Україні. Отримано 3 https://kiis.com.ua/?lang $=$ ukr\&cat $=$ reports\&id $=904 \&$ page $=1 \& \mathrm{t}=10$

Корзун, О. И. (2017). Как переехать в другую страну и не умереть от тоски по родине. 
Бардіна-Віж’є, О. (2019). Іноземні студенти в Україні: чинники адаптації. Вісник ХНУ імені B. H. Каразіна. Серія «Соиіологічні дослідження сучасного суспільства: методологія, теорія, методи», (1122), 108-112. Отримано 3 https://periodicals.karazin.ua/ssms/article/view/13546

Беспалова, Н., Самойленко, С. (2015). Культурний шок та психологічна адаптація студентівіноземців. «Молодий вчений», № 1 (16), 166-168.

Добротвор, О., Щербина, І. (2017). Адаптація іноземних студентів у навчальний процес ВН3 України. Вісник Національного авіаційного університету. Серія: Педагогіка, Психологія, 10.

«Інша раса». В Україні роквітає расова нетерпимість? (2008). Отримано 3 https://www.radiosvoboda.org/a/1139522.html.

Ручка, А., Танчер, В. (2017). Багатокультурність: чинники, проблеми, нові перспективи суспільного розвитку. Український соціологічний журнал, 17(1-2), 9-16. Отримано 3 https://periodicals.karazin.ua/usocjour/article/view/11441

Український державний центр міжнародної освіти, (2019). Іноземні студенти в Україні. Отримано 3 https://studyinukraine.gov.ua/zhittya-v-ukraini/inozemni-studenti-v-ukraini/

\section{References}

KIIS Archive, (2018, 2019). Interethnic prejudice in Ukraine. Retrieved from https://kiis.com/?lang=en\&cat=reports\&id=904\&page $=1 \& \mathrm{t}=10$

Korzun, O.I. (2017). How to move to another country and not die from homesickness.

Bardina Vizier, O. (2019). Foreign students in Ukraine: adaptation factors. Journal of VN Karazin KhNU. Series "Sociological studies of modern society: methodology, theory, methods", (1122), 108-112. Retrieved from https://periodicals.karazin.ua/ssms/article/view/13546

Bespalova, N., Samoilenko, S. (2015). Cultural shock and psychological adaptation of foreign students. «Young Scientist», № 1 (16), 166-168.

Dobrovor, O., Shcherbina, I. (2017). Adaptation of foreign students into the educational process of Ukrainian universities. Journal of the National Aviation University. Series: Pedagogy, Psychology, 10.

"Another race". Is racial intolerance blossom in Ukraine? (2008). Retrieved from https://www.radiosvoboda.org/a/1139522.html

Ruchka, A., Tancher, B. (2017). Multiculturalism: factors, problems, new perspectives on social development. Ukrainian sociological journal, 17 (1-2), 9-16. Retrieved from https://periodicals.karazin.ua/usocjour/article/view/11441

Ukrainian State Center for International Education (2019). International students in Ukraine. Retrieved from https://studyinukraine.gov.ua/zhittya-v-ukraini/inozemni-studenti-vukraini/

\section{Contact information:}

Andriushchenko Mariia mariaandrusenko66@gmail.com

Shkolyar Mariana

shkolyar.maryana@gmail.com 